\title{
Application of Knowledge Management Systems for Counseling of First Middle School Students: A-SIMPeko Middle School Student
}

\author{
Agnes Novita $^{1,}$ Isnin Faried ${ }^{2}$ and Dwi Atmodjo WP ${ }^{3}$ \\ Fakultas Teknology Information \\ IKPIA Perbanas- Jakarta \\ Indonesia
}

\begin{abstract}
Guidance and Counseling (BK) in one of the Swsata schools in East Jakarta has been done well so it is very helpful for the counselee. The counselee can develop his potential and solve the problems at hand. This BK process occurs very intensively and always develops according to the conditions and needs of the counselee. At present many cases of BK occur and must be resolved immediately so that it is felt necessary for the media to store the results of counseling so that it can be used again as a counselor's reference in handling similar or similar cases. The media needed is not just a store but can be used to retrieve it quickly as well as record it as a Knowledge Base. Based on these needs it is necessary to make a system that can save and take the results of counseling with the Knowledge Management (KM) approach. BK activities that begin with the discussion, give advice or solutions to the counselee, plan problem solving until the implementation of problem-solving has the characteristics of KM. The results of this study are the development of an Information and Guidance and Counseling information system that implements a Knowledge Management System approach that resolves the storage needs and restatement of counseling results.
\end{abstract}

Keywords: Guidance and Counseling, Knowledge Base, Knowledge Management System, Counseling.

\section{INTRODUCTION}

Counseling and guidance services in schools are an effort to help students in the development of personal life, social life, learning activities, and career planning and development. Counseling and guidance services facilitate the development of individual, group and / or classical students, according to their needs, potential, talents, interests, developments, conditions, and opportunities. This service also helps overcome weaknesses and obstacles and problems faced by students. Counseling guidance also facilitates students who are subsequently called counselees, in order to be able to develop their competency [8]. Counseling is a very important activity in counseling activities in schools and outside schools, counseling is an important activity in changing the thoughts, attitudes, and behavior of individuals, which in the process must be carried out by a professional counselor. The students' success in learning is characterized by the success of compiling the program, success in the process of implementing the program, and the success of satisfying learning outcomes obtained by students. The success will not be realized without the support and cooperation of the Principal, the School Administration who has prepared all the necessary equipment, subject teachers, and not forgetting the role of the BK Counselor in school [9].

One of the junior high schools in East Jakarta is currently providing guidance and counseling services in their schools to help students develop their personal, social life and learning, planning and career development. But at this time in the implementation of counseling the junior high school was still using paper or book media for recording, and this turned out to be still much done in other schools [10], [12]. The process of recording like this according to the BK teachers resulted in the need for extra effort for BK teachers if there is a need to see (return) counseling data that students already have, especially if they experience a similar case or in the development monitoring activities of students who have consulted. While looking at the counseling process above, it is certain to produce a large and complex number of notes and information. Documents regarding this counseling record have not been managed properly, even though this document is very valuable.

To overcome the problem regarding the manual recording, it is necessary to apply a Knowledge Management System. This Knowledge Management System can record existing counseling, save qualitative data (descriptive of events, student problems and solutions given by counselors). The existing record or recording characters also have the potential to always change or develop considering the events and problems experienced by students may have similarities but the solutions provided are not 
always the same because they are adapted to the development of the situation and era. By looking at these two things, the concept of the Knowledge Management System (KMS) is needed. The technology that will be used using the web base with consideration of applications is easier to implement if there is a need to share resources and use (sharing resources and sharing modules). Other needs can later be developed in addition to being accessible to BK teachers, and school administration can also be accessed by parents of students. Even for broader needs this application can be used by counselors (BK teachers) other good schools counselors who experience similar problems but of course this application by first "keeping students' identities" secret. Deposit data in this application will always be kept confidential, especially the identity of students with the application of user access security. Applications developed based on the model created will record some data including student data, value data, attendance of consulted students, problematic student data, and other data that will be stored in a database, and from existing databases will make it easier for BK teachers to see history students consult, make solutions based on problem history and family background of students, monitor and sustainability actions for students.

\section{THEORETICAL FOUNDATION}

\subsection{Guidance and counseling}

According to the operational guidelines for the administration of counseling and counseling for junior high schools (SMP), the Ministry of Education and Culture of the Directorate General of Teachers and Education Personnel in 2016 said that guidance and counseling in educational units was held to help students / counselees achieve their development tasks [11] . The developmental tasks in question include: achieving mature friendship relationships; achieve social roles according to gender; accepting his physical condition and using it effectively; achieve emotional freedom from parents and other adults; prepare yourself to live in a household; prepare for his career; achieve a set of values and ethical systems that guide his behavior; and achieving behavior that can be socially accountable. Guidance and counseling teachers or counselors in junior high school play a role in helping students achieve personal, social, learning and career development. At this level, guidance and counseling teachers or counselors carry out all the functions of guidance and counseling, namely functions of understanding, facilitation, adjustment, distribution, adaptation, prevention, improvement, advocacy, development, and maintenance.

In his research [8] stated that the quality of guidance and counseling services in schools was low, it was because the teacher and student ratio was not appropriate (1 teacher for 150 students), the teacher was still in duplicate. Whereas [10] concluded that the recording of student violations carried out by picket officers and counseling teachers was still done manually, namely writing on the paper form. Pure research results are in line with research [12], which states that most student data recording and monitoring activities are still done manually, this is why the BK teacher is confused about finding personal and historical data of students.

The conclusion of the 3 studies above is that the teacher manages student data a lot, but unfortunately the management of student data is still done manually, as a result the BK teacher has difficulty finding student data, looking for student history, making reports and more. To overcome this, [10] designed a web-based counseling application, while [12] created a student violation data processing application that was integrated with sms gateway.

\subsection{Knowledge Management}

Conceptually, Knowledge Management is an organizational activity in managing knowledge as an asset, it requires efforts to channel the right knowledge to the right people in a fast time, so that they can interact with each other, share knowledge and apply it to daily work to improve organizational performance [ 5]. Understanding Knowledge Management (KM) [7] is planning, gathering and organizing, leading and controlling data and information that has been combined with various forms of thought and analysis from various kinds of competent sources. So, the main principle of Knowledge Management is to encourage organizations to "know what they know". Knowledge Management is also a process of capturing and using expertise that is useful anywhere in the organization both in the form of documents and databases (tacit), or still in the human head (explicit) [2]. Whereas [3] defines knowledge management as an activity in finding (discovery), capturing (capture), sharing (sharing) and using knowledge (application) in order to improve work effectiveness to support the achievement of organizational goals. 


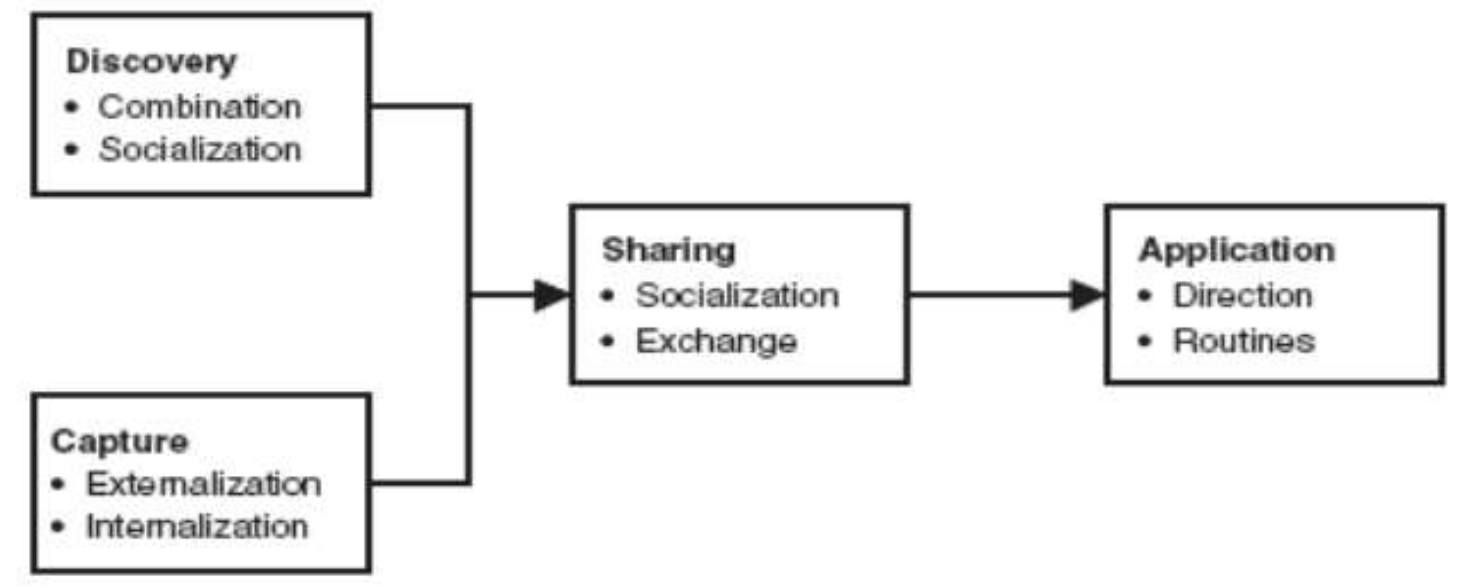

Figure 1, Knowledge Management Process [3]

In line with the implementation of Knowledge Management, the main capital of the organization is no longer focused on tangible assets (land, buildings, money), but has changed into intangible assets (brand recognition, patent, customer loyalty) which are manifestations of creativity and innovation that are based on knowledge. The innovation process depends a lot on knowledge, especially because knowledge represents a field, much deeper than conventional data, information, and logic. Therefore, the power of knowledge lies in its subjectivity that underlies the values and assumptions that form the foundation of the learning process. From this understanding, it can be said that Knowledge Management (KM) and human resources are important elements in running every business.

All organizations certainly can store, access and disseminate knowledge in many activities, but the important question is "what value and products they deliver by the effective use of knowledge capital". Humans in the context of knowledge management are knowledge sources, innovations, and updates. Humans are intangible resources that are believed to be able to develop knowledge or knowledge. That is, the better the knowledge or knowledge received by humans, then the knowledge will be able to create new knowledge that is even better [5].

In his research [3] concluded that knowledge management can be made more organized, collecting tacit and explicit knowledge can be done by entering new information in the forum. Searching for procedures or documents can be done on this KMS so that it will improve service time and accuracy in implementing procedures. Thus [6] states that knowledge is one of the assets of the company / agency and can be a competitive advantage if it can be managed properly. Management of this knowledge can utilize a system called Knowledge Management System (KMS), as in STMIK AUB can be implemented by KMS to support the improvement of the performance of its employees in terms of improving academic services. The success in implementing the KMS is not only based on a system that is built / created and existing technology, but also needs support and awareness from each individual involved in it to be able to maximize the use of the KMS.

\section{METHODOLOGY}

The methodology used in this study is as follows:

- Implementation of the Model and Refinement of Prototypes that have been done before. The improvement meant is to complete the entire counseling process into a database application. Furthermore, this database application is used as a data source for knowledge management system applications which is the main objective of the research. The development method used is the system development method, namely System Development Life Cycle (SDLC)

- Trial application results from model implementation. The trial phase adopts a system development method, namely Agile Model where in this activity many involve the user (the school, especially the BK teacher) try the application that is made so that the system shortcomings are known. During the trial phase here at the same time will be carried out storage of counseling data into a "database container" where this container will be used as a data source for knowledge management systems.

- The next step is to test the counseling knowledge management system where in this system the data and information presented are only knowledge that has been stored in the existing database, especially handling problems that have been handled by BK teachers and how to solve them. The presentation of this information has been through a data processing mechanism to protect data that is considered confidential, especially those relating to students in junior high school.

- When the results of the trial have been analyzed with the results of a feasible application to be implemented, the next stage that is carried out is to conduct a socialization to the BK teacher. The socialization will include training in using the application system especially for a number of prioritized users, including internal counseling teachers, several homeroom teachers, representatives and local school principals. 
International Journal of Advances in Scientific Research and Engineering (ijasre), Vol 5 (2), February-2019

- The last step to be carried out is to monitor the above activities while at the same time carrying out system maintenance when problems arise due to user errors or very technical problems that result in the system being built not running perfectly.

The whole stage is described as follows.

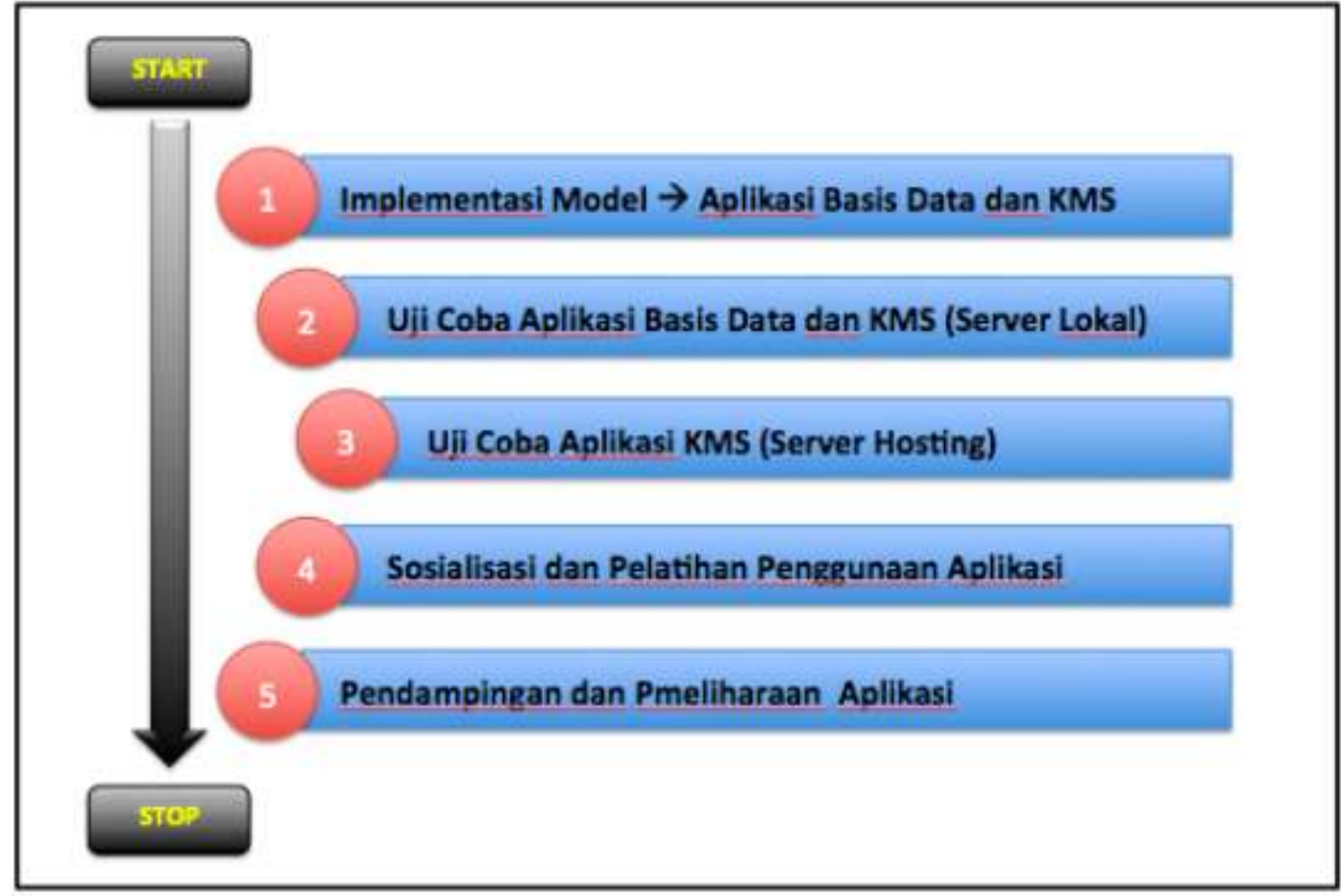

Figure 2. Stage of Research in KM Counseling Guidance

\section{ANALYSIS AND RESULTS}

Database Design for Counseling Guidance Services (BK)

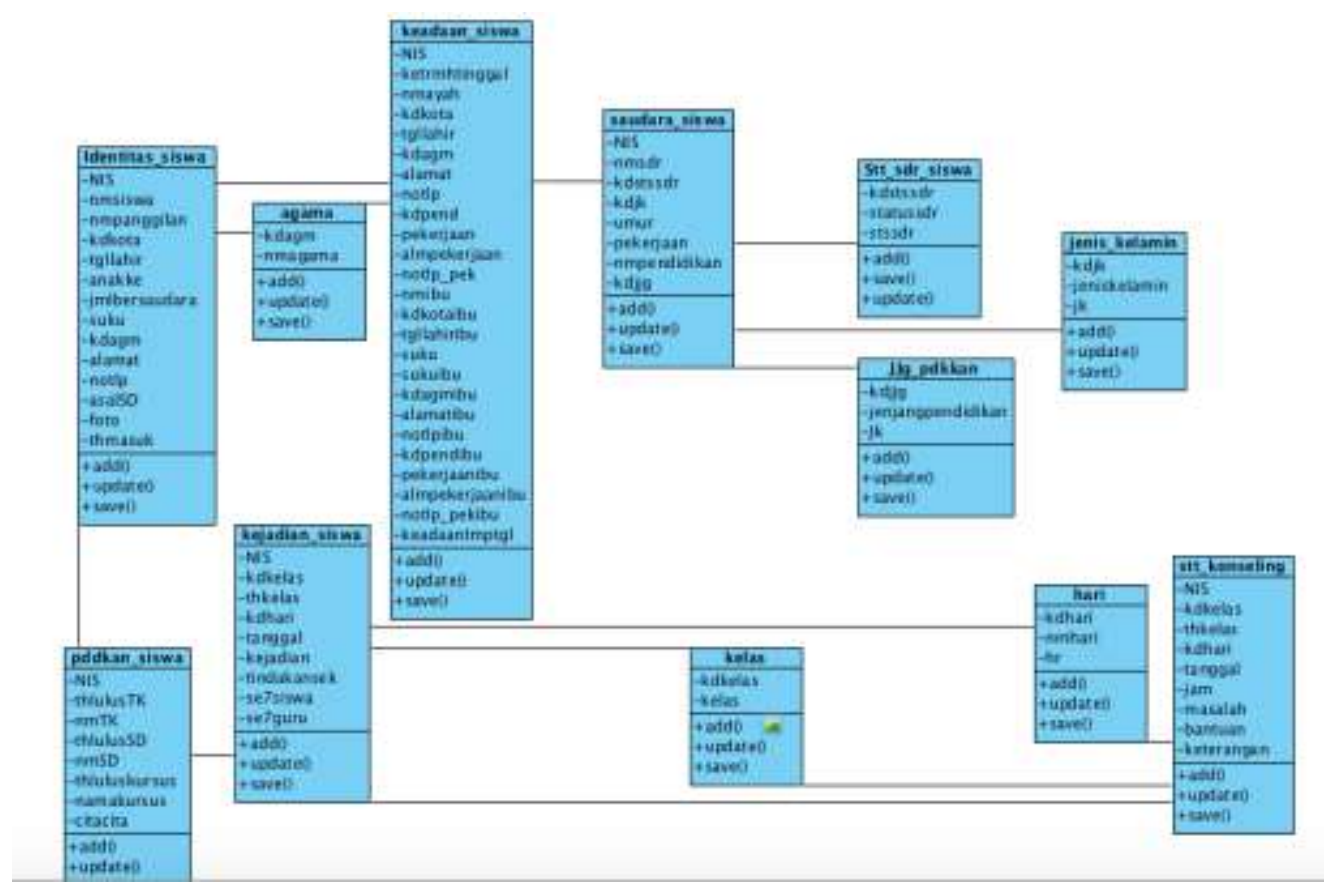

Figure 3. KM Counseling Guidance Database 


\subsection{Designing BK service system}

The service application system created is adjusted to the current place of research covering two major activities, namely the first process of recording the process of daily counseling activities conducted by BK teachers. The second process is the management of daily counseling recording data into the basis of knowledge management which is implemented into a Knowledge Management System.

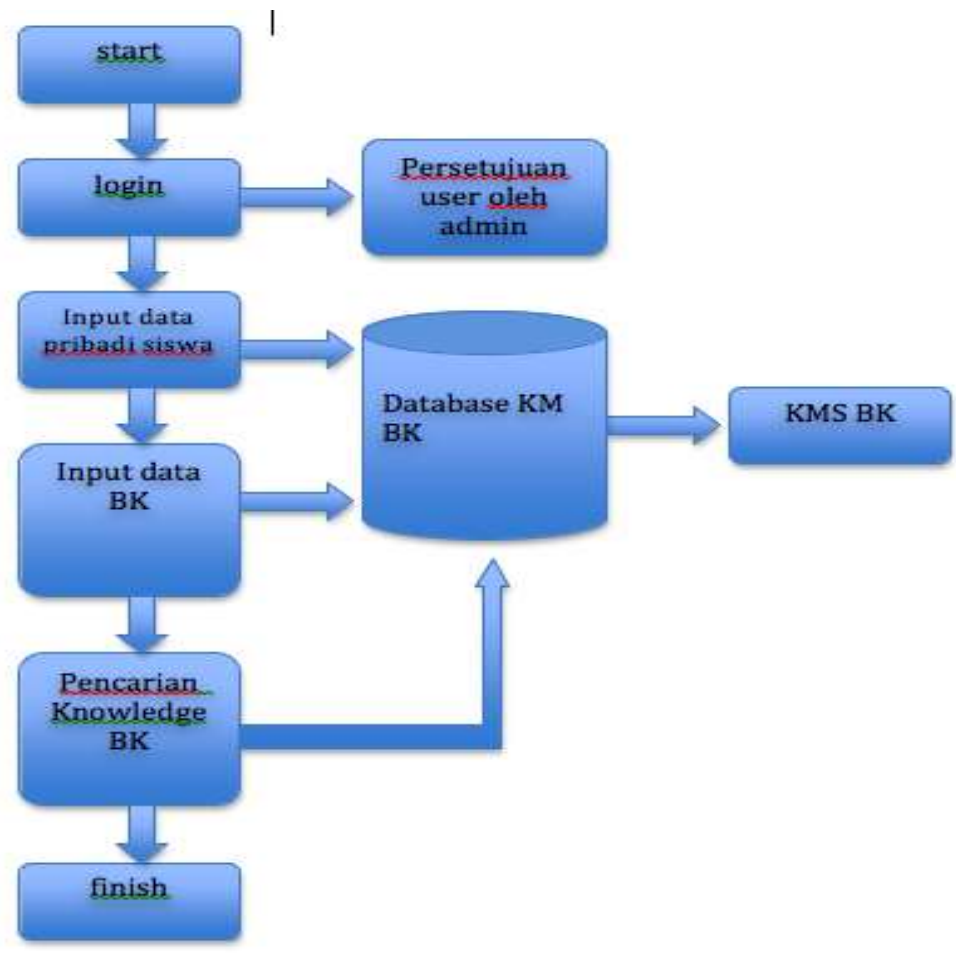

Figure 4. KMS framework

The application of this system consists of four major groups, namely master data, student data, counseling data and Knowledge Management.

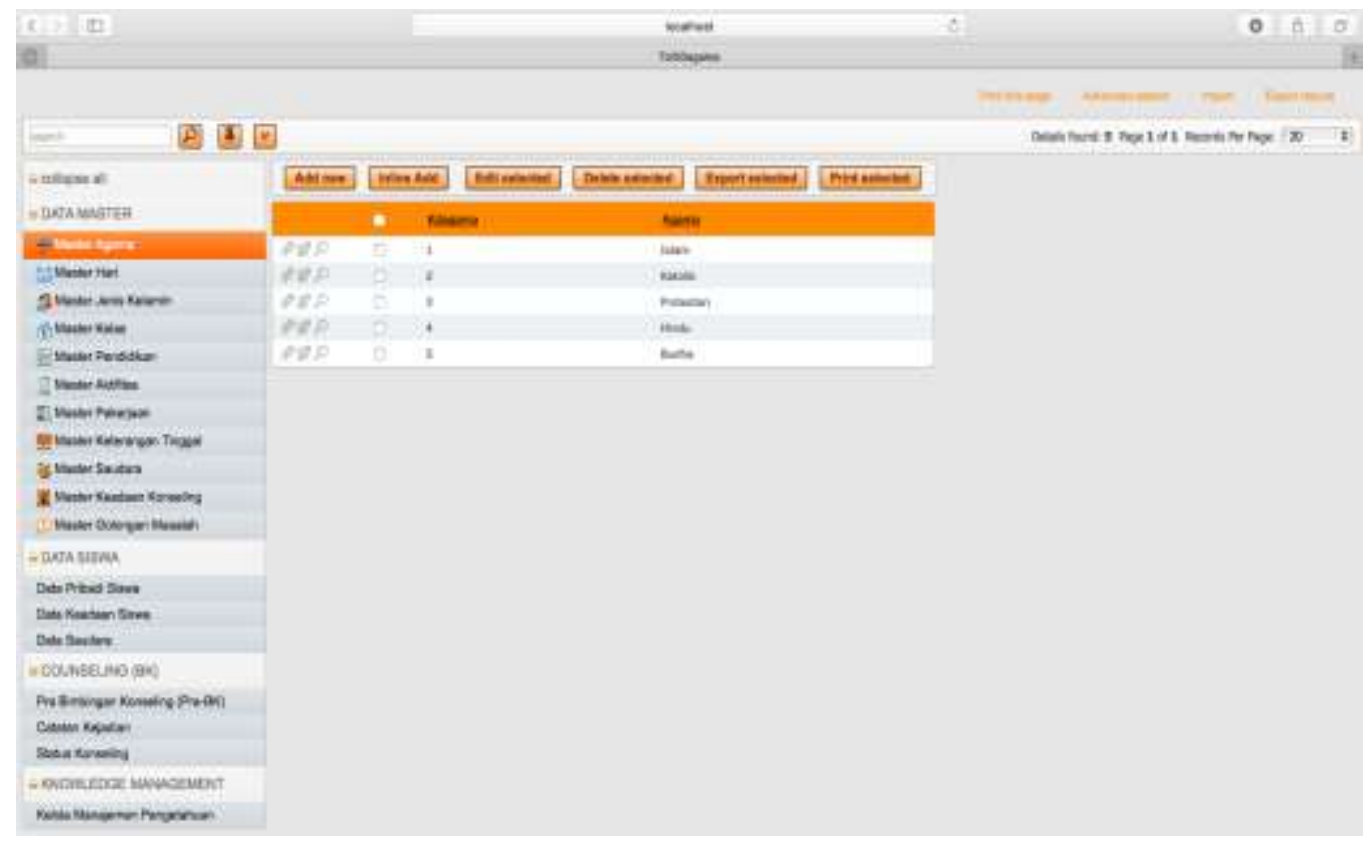

Figure 5. Master data

This student data is very important to know the personal details of students, as well as the condition of students and your data. If this student data is complete, it will facilitate the search for the cause of the problem and also the problem solving if there is a problem with the student. Because not infrequently the problems faced by students start from the personal students and families. 
International Journal of Advances in Scientific Research and Engineering (ijasre), Vol 5 (2), February-2019

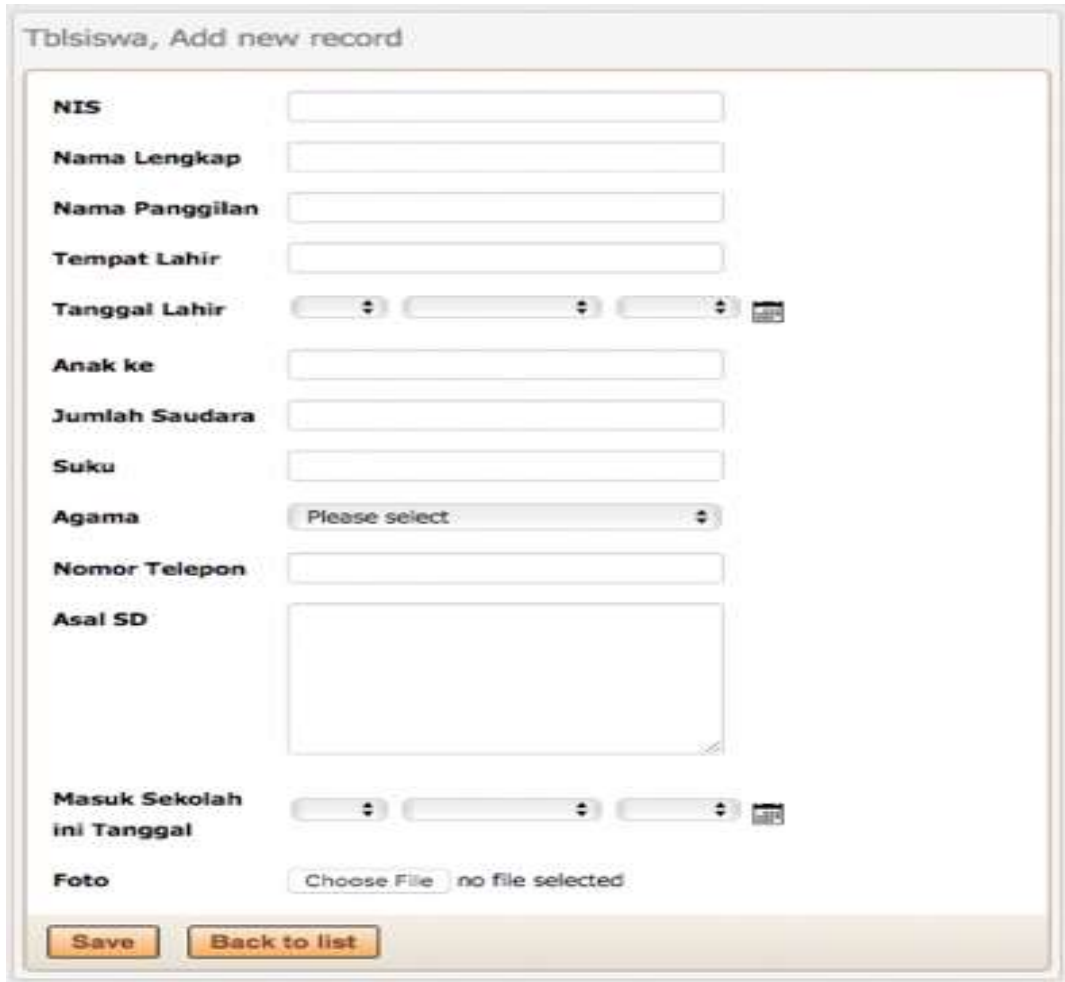

Figure 6 Student personal data

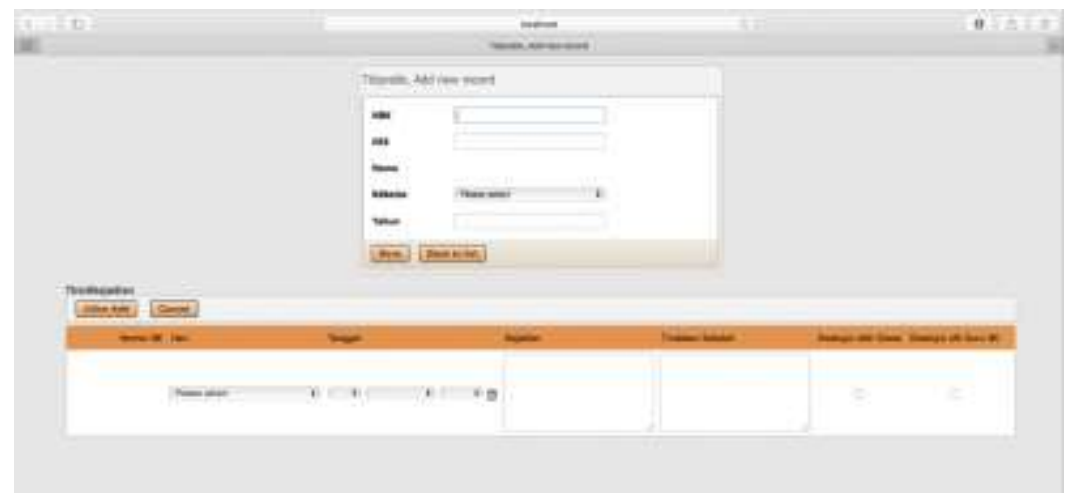

Figure 5. pre guidance counseling data and event records

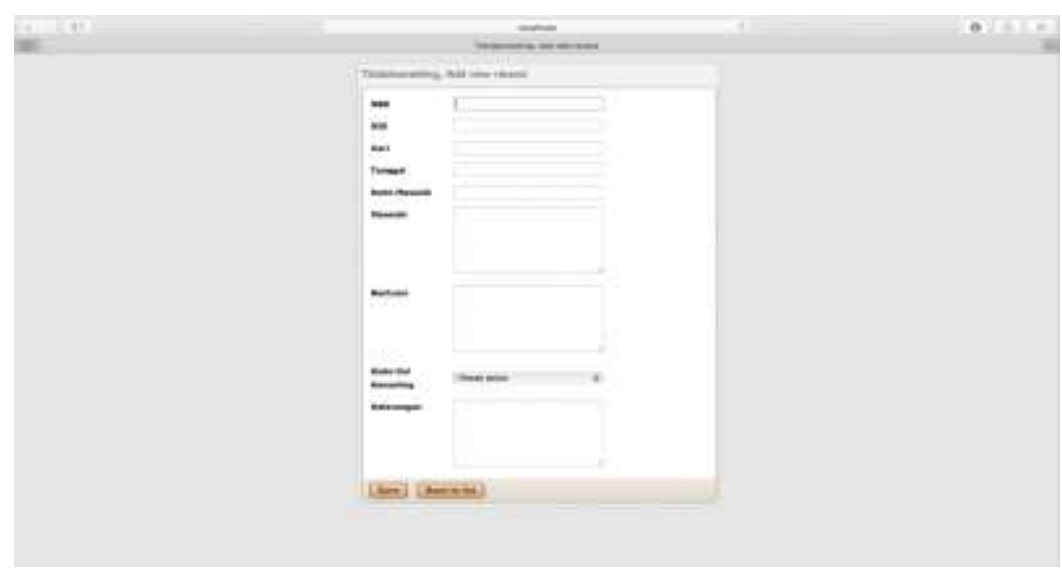

Figure 5. Counseling status

Every time there is a problem counseling the BK teacher records the problem and the solution in the form below (knowledge management data). Based on the contents of the form, the knowledge data on handling BK cases can be shared with fellow BK teachers, with sharing data, the BK teacher has a reference in making decisions or resolving a student problem. 


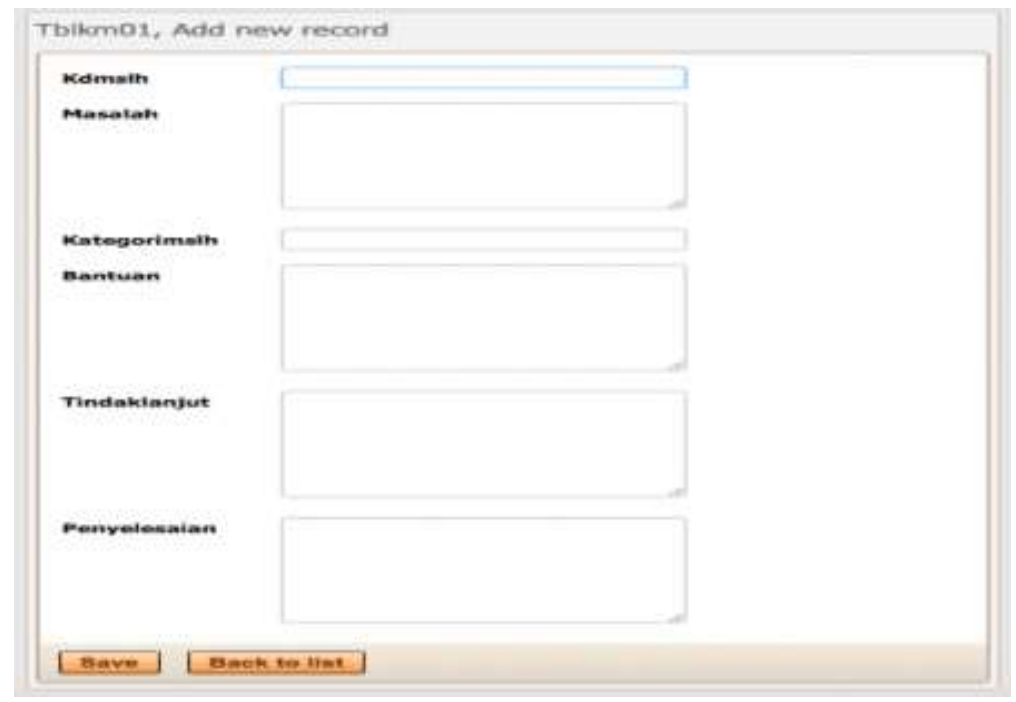

Figure 5. Data management knowledge

\section{CONCLUSION}

1. All problems and solutions regarding BK are stored in the system, so that it can facilitate the BK teacher, homeroom teacher in managing data.

2. With the knowledge management BK information system is very helpful BK teachers in making decisions in providing counseling guidance to students.

3. With this information system, the teacher can provide a faster solution.

4. Teachers can make reports faster.

\section{REFERENCES}

1. Achmad Juntika Nurihsan,Bimbingan dan Konseling dalam Berbagai Latar Kehidupan (Bandung : PT Refika Aditama, 2009)

2. Awad, E, M., \& Ghaziri, H, M. (2004). Knowledge Management. New Jersey: Pearson Education, Inc.

3. Becerra-Fernandez, I., Sabherwal, R. (2010). Knowledge Management Systems and Processes. New York: M.E. Sharpe, Inc.

4. Erhamwilda. 2009. Konseling Islami. Yogyakarta : Graha Ilmu.

5. Harjanto, 2010, Knowledge Management di Perguruan Tinggi. Binus Business Review Vol. 1 No.2, November 2010: 407-415

6. Hartini et al., 2012. Sistem Manajemen Pengetahuan Berbasis Standar Operasional Prosedur Untuk Meningkatkan Kinerja Pegawai. Jurnal Sistem Informasi Bisnis.

7. Hendrik. (2003). Sekilas tentang knowledge management. Artikel Populer IlmuKomputer.Com, copyright@2003IlmuKomputer.Com.

8. H. Kamaluddin. 2011. Bimbingan dan Konseling Sekolah. Jurnal Pendidikan dan Kebudayaan, Vol 17, Nomor 4, Juli 2011

9. Mahdi. Peran Guru Bimbingan dan Konseling dalam Meningkatkan Kesuksesan Belajar Siswa di SMA Negeri 1 Depok Sleman Yogyakarta. Jurnal Edukasi. Jurnal Bimbingan Konseling. P-ISSN: 2460-4917,e-ISSN:2460-5794

10. Murni et al. 2015. Aplikasi Bimbingan Konseling Berbasis Web di SMP Negeri 1 Teras Boyolali. Varia Pendidikan, Vol 27, No.2, Desember 2015. ISSN: 0852-0976

11. Panduan Operasional Penyelenggaraan Bimbingan Dan Konseling Sekolah Menengah Pertama (SMP) . Kementerian Pendidikan Dan Kebudayaan Direktorat Jenderal Guru Dan Tenaga Kependidikan 2016

12. Rizki et al. 2017. Aplikasi Pengolahan Data Pelanggaran Siswa Pada SMK Yayasan Pendidikan Teknologi 1 Purbalingga Terintegrasi Dengan SMS Gateway. Jurnal Telematika Vol. 10 No.2 Agustus 2017. ISSN:1979-925X, e-ISSN:2442-4528

13. Robby Tan. 2010. Perancangan Model Manajemen Pengetahuan Menggunakan Model Nonaka Takeuchi (Studi Kasus Administrasi Akademik). Jurnal Informatika, Vol 6, No 1, Juni 2010. 